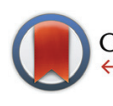

CrossMark

<click for updates

Cite this: Food Funct., 2016, 7, 1251

Received 10th December 2015,

Accepted 10th January 2016

DOI: $10.1039 / \mathrm{c} 5$ fo01530h

www.rsc.org/foodfunction

\section{Dietary protein intake and human health}

\author{
Guoyao Wu
}

A protein consists of amino acids (AA) linked by peptide bonds. Dietary protein is hydrolyzed by proteases and peptidases to generate AA, dipeptides, and tripeptides in the lumen of the gastrointestinal tract. These digestion products are utilized by bacteria in the small intestine or absorbed into enterocytes. AA that are not degraded by the small intestine enter the portal vein for protein synthesis in skeletal muscle and other tissues. AA are also used for cell-specific production of low-molecular-weight metabolites with enormous physiological importance. Thus, protein undernutrition results in stunting, anemia, physical weakness, edema, vascular dysfunction, and impaired immunity. Based on short-term nitrogen balance studies, the Recommended Dietary Allowance of protein for a healthy adult with minimal physical activity is currently $0.8 \mathrm{~g}$ protein per kg body weight (BW) per day. To meet the functional needs such as promoting skeletal-muscle protein accretion and physical strength, dietary intake of 1.0, 1.3, and $1.6 \mathrm{~g}$ protein per kg BW per day is recommended for individuals with minimal, moderate, and intense physical activity, respectively. Long-term consumption of protein at $2 \mathrm{~g}$ per $\mathrm{kg} \mathrm{BW}$ per day is safe for healthy adults, and the tolerable upper limit is $3.5 \mathrm{~g}$ per kg BW per day for well-adapted subjects. Chronic high protein intake (>2 g per kg BW per day for adults) may result in digestive, renal, and vascular abnormalities and should be avoided. The quantity and quality of protein are the determinants of its nutritional values. Therefore, adequate consumption of high-quality proteins from animal products (e.g., lean meat and milk) is essential for optimal growth, development, and health of humans.

\section{Introduction}

A protein usually contains various amounts of 20 different amino acids (AA) linked via peptide bonds. ${ }^{1}$ The English word protein originated from the Greek "proteios", meaning prime or primary. This term is very appropriate in nutrition, because protein is the most fundamental component of tissues in animals and humans. ${ }^{2}$ Dietary protein has no nutritional value unless it is hydrolyzed by proteases and peptidases to AA, dipeptides, or tripeptides in the lumen of the small intestine (Fig. 1). Thus, the content, digestibility coefficients, and relative proportions of AA in dietary protein are the determinants of its nutritional value. ${ }^{3}$

AA provide nitrogen, hydrocarbon skeletons, and sulfur (essential components of organisms), and cannot be replaced by any other nutrients (including carbohydrate and lipids) because neither nitrogen nor sulfur is made in the body. AA are essential precursors for the synthesis of proteins, peptides, and low-molecular weight substances (e.g., glutathione, creatine, nitric oxide, dopamine, serotonin, RNA and DNA) with enormous physiological importance. ${ }^{4,5}$ Dietary glutamate, glut-

Departments of Animal Science and Medical Physiology and Faculty of Nutrition, Texas A\&M University, College Station, Texas 77843, USA. E-mail: g-wu@tamu.edu amine and aspartate are major metabolic fuels for the mammalian small intestine in the fed state, whereas glutamine in the arterial blood is almost the exclusive source of energy for this organ in the post-absorptive state. ${ }^{2}$ In addition, glutamine provides $\sim 50 \%$ and $35 \%$ of ATP in lymphocytes and macrophages, respectively, to sustain immune responses. ${ }^{6}$ Thus, AA are essential for the health, growth, development, reproduction, lactation, and survival of organisms. This is graphically indicated by metabolic disorders, kwashiorkor (caused by a severe deficiency of protein) and marasmus (caused by the severe deficiency of both protein and energy) in humans, particularly in many children of developing nations. ${ }^{7}$ Less severe forms of dietary protein deficiency occur in elderly subjects (e.g., the home-bound elderly), including those in developed countries, thereby increasing their susceptibility to metabolic and infectious diseases. ${ }^{8}$ The other end of the nutrition spectrum is the overconsumption of dietary AA and protein from meals and excessive supplementation, which can also compromise the health of humans, particularly those with hepatic or renal dysfunction. ${ }^{9}$

Knowledge about AA biochemistry and nutrition provides the necessary foundation to optimize the recommended values for dietary requirements of protein by humans and to understand the potential impacts of dietary protein on health. Nitrogen balance studies have traditionally been employed to 


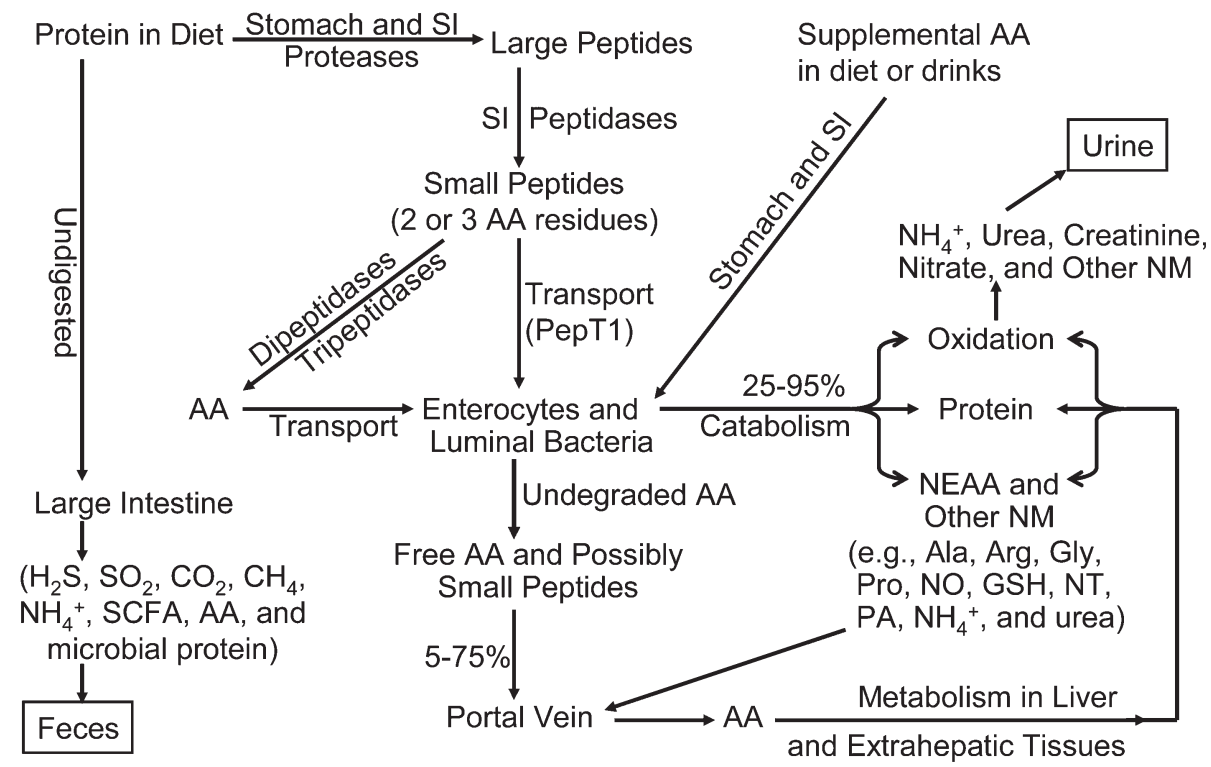

Fig. 1 Digestion of dietary protein in the gastrointestinal tract of the small intestine in monogastric animals, including humans. All diet-derived AA undergo various degrees of catabolism by luminal bacteria and some of them are oxidized by enterocytes. For example, $95 \%$ of dietary glutamate is utilized by the small intestine, and only $5 \%$ of dietary glutamate enters the portal circulation. $A A$ metabolites are excreted in feces and urine. $A A=$ amino acids; $\mathrm{GSH}=$ glutathione; NEAA = nutritionally nonessential $\mathrm{AA} ; \mathrm{NM}=$ nitrogenous metabolites; $\mathrm{NT}=$ nucleotides; PepT1 $=\mathrm{H}^{+}$gradientdriven peptide transporter 1 ; SCFA = short-chain fatty acids; $\mathrm{SI}=$ small intestine.

determine the requirements of dietary protein and AA by humans. ${ }^{10}$ Over the past three decades, studies involving AA tracers have been used along with the $\mathrm{N}$ balance technique to determine the dietary requirements of "nutritionally essential AA" (EAA), which are AA whose carbon skeletons are not synthesized or are inadequately synthesized by animal cells. In recent years, there has been growing interest in the dietary requirements of synthesizable AA by mammals, including humans. ${ }^{11,12}$ The major objective of this review is to highlight historic studies of dietary protein intake by humans and recent issues concerning the effects of protein nutrition on health, particularly the preservation of skeletal-muscle mass and function in adults.

\section{A brief account of historic research on dietary $A A$ requirements by humans}

\subsection{Research in the early 1900s}

A free-living person eats what he/she likes. However, it is scientifically relevant to ask how much dietary protein or AA a human being needs to fulfill his/her physiological needs and prevent or ameliorate a catabolic state (e.g., sarcopenia in adults). There is a rich history of this research subject over the past two centuries, but it is also a source of continuing debate and disagreement among the investigators. ${ }^{1,11,13-15}$ Based on the amounts of protein consumed by a group of German workmen doing moderate physical work, von Liebig estimated in 1840 that the average adult would require a dietary intake of $120 \mathrm{~g}$ protein per day. ${ }^{16}$ Extrapolating results from canine studies, von Voit suggested in 1881 a dietary intake of $118 \mathrm{~g}$ protein per day for the average adult. ${ }^{17}$ In 1902, Atwater recommended a dietary intake of $125 \mathrm{~g}$ protein per day for the average adult, because he thought that U.S. workmen generally worked harder than Germans. ${ }^{18}$ However, Chittenden challenged these values of protein intake in 1904, based on his observations that: (a) adults remained healthy and in $\mathrm{N}$ balance for six months on daily diets containing 61 to $62 \mathrm{~g}$ protein; and (b) college student athletes consuming $64 \mathrm{~g}$ protein per day maintained their levels of athletic performance and well-being. ${ }^{19}$

\subsection{Research between 1940s and 2010s}

Work on dietary requirements of AA by humans was initiated by Rose in the 1940s. ${ }^{10}$ Rose designed a basal diet to contain $\mathrm{N}$-free food ingredients, including cornstarch, sucrose, protein-free butterfat, corn oil, inorganic salts, and a vitamin mixture. The subjects consumed, for 8 days, an AA mixture lacking a tested $\mathrm{AA}$, and $\mathrm{N}$ balance was the criterion for adequacy or inadequacy of the rations. In 1950, he identified methionine and valine as EAA for young adults. Subsequently, Rose reported that threonine, isoleucine, leucine, lysine, phenylalanine, tryptophan and valine as EAA for humans. In these experiments, the removal of an EAA from the diet resulted in a negative $\mathrm{N}$ balance, low appetite, extreme fatigue, and nervous irritability. Conversely, these symptoms disappeared promptly after addition of the missing EAA to the ration. In contrast, Rose found that healthy young men fed a 
diet lacking one of the following AA could maintain $\mathrm{N}$ balance: alanine, arginine, aspartate, cysteine, glutamate, glycine, proline, serine, and tyrosine. ${ }^{10}$ Over the past half century, isotopic tracer studies have been undertaken to determine the quantitative requirements of dietary EAA by infants, children, and adults. ${ }^{11}$ Like the fractional rates of tissue protein synthesis, dietary EAA requirements [expressed as mg per kg body weight (BW)] by humans decrease with increasing age between birth and adulthood. ${ }^{20}$

\section{Methods for determining dietary requirements of $A A$ and protein by humans}

\subsection{General considerations}

In assessing the dietary requirements of AA and protein by humans, oxidation of AA in the body should be taken into consideration (Fig. 2). First, regardless of AA balance in the diet, when the dietary intake of AA or protein is augmented, the oxidation of AA is increased according to the substrate-enzyme relationship of Michaelis-Menten kinetics. ${ }^{1}$ Excessive AA (probably except for glutamine in skeletal muscle) must be oxidized to $\mathrm{CO}_{2}$, water, and urea. Second, when the dietary intake of AA or protein is at the optimal amount for protein synthesis, the oxidation of AA is at a minimum level. ${ }^{21}$ Third, when the dietary intake of AA or protein is below the animal's requirements, the oxidation of AA is reduced to spare AA for protein synthesis. This is partly because the enzymes involved in protein synthesis (e.g., tRNA-AA synthases) have much lower $K_{\mathrm{M}}$ values for AA substrates than the enzymes that degrade AA. ${ }^{1}$ This means that AA are preferentially channeled to the pathway of protein synthesis rather than AA catabolism. There- fore, only a small fraction of dietary AA are available for oxidation in animals fed an AA-balanced diet. Fourth, in a protein-adequate diet, an excess of a specific AA (usually an EAA) would result in an increase in its oxidation, but not necessarily the oxidation of other AA. In contrast, when an EAA is deficient in a diet, the oxidation of other AA is increased progressively with the increasing dietary intake of AA or protein. This is because the short supply of this AA limits the utilization of other AA for protein synthesis and all excessive AA are degraded in a tissue-specific manner. These interrelationships between AA oxidation and dietary intake of AA or protein with or without a deficiency of one EAA are illustrated in Fig. 1.

\subsection{Nitrogen balance studies for determining dietary requirements of $\mathrm{AA}$ and protein}

Replacement of obligatory utilization and loss of AA is the basis of protein requirements by healthy adults. ${ }^{22}$ This is reflected by the amounts of $\mathrm{N}$ in the urine, feces, and integument. The principle of $\mathrm{N}$ balance studies is that when there is no $\mathrm{N}$ accumulation in the body (e.g., healthy adults), $\mathrm{N}$ intake from the diet should be equal to $\mathrm{N}$ excretion in various forms including: (a) urea, ammonia, nitrite, nitrate, AA, and other nitrogenous substances in urine; (b) nitric oxide (NO) gas; and (c) fecal nitrogenous substances ( $\mathrm{N}$ output). $\mathrm{N}$ balance can be determined for the whole body or a specific tissue, and is the classic approach for measuring dietary requirements of proteins and AA by humans of all ages. In those studies, complete $24 \mathrm{~h}$ urine and fecal collections should be made from the subjects. Minimum urinary and fecal loss of $\mathrm{N}$ from healthy adult humans are remarkably constant, which are 36 and $10 \mathrm{mg}$ per $\mathrm{kg}$ BW per day, respectively. ${ }^{13}$ The loss of $\mathrm{N}$ via other routes such as skin, sweat, hair, nails, and respiration has been estimated to be $8 \mathrm{mg}$ per $\mathrm{kg}$ BW per day in healthy adults. ${ }^{20}$

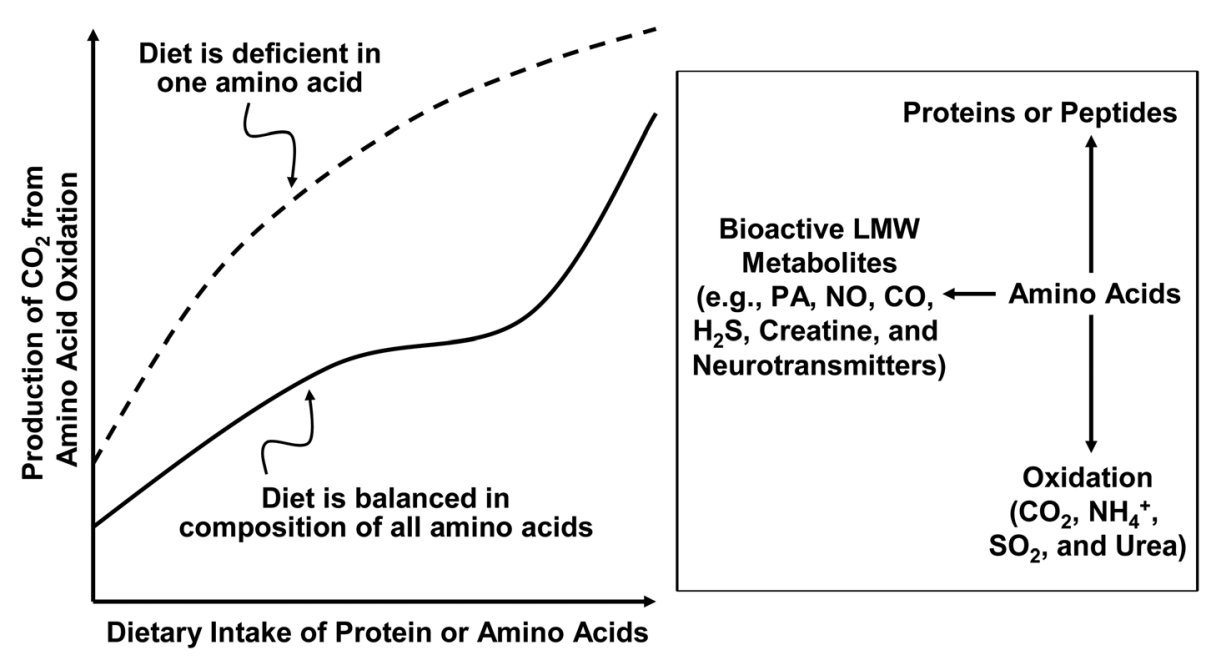

Fig. 2 The interrelationships between AA oxidation and dietary intake of AA in humans. In human subjects fed a protein-adequate diet, an excess of a specific AA results in an increase in its oxidation but not necessarily the oxidation of other AA. In contrast, when an AA (particularly an AA not synthesized by animal cells) is deficient in a diet, the oxidation of other AA is increased progressively with the increasing dietary intake of AA or protein. $\mathrm{LMW}=$ low molecular weight; $\mathrm{NO}=$ nitric oxide; $\mathrm{PA}=$ polyamines. 
Growth in children results from protein deposition, namely a positive $\mathrm{N}$ balance, and this is also true for skeletal-muscle builders among athletes.

\subsection{Factorial method for determining AA requirements}

Dietary requirements for AA by the whole body or a tissue of interest (e.g., the small intestine) can be estimated on the basis of factorial analysis, namely, the sum of fecal and urinary $\mathrm{N}$ in response to a protein-free diet (maintenance), $\mathrm{AA}$ deposited in the body, and AA excreted as important products (e.g., milk and fetal growth). ${ }^{23}$ For certain AA, the factorial method can also be based on the sum of the needs for the AA for metabolic pathways and obligatory losses of the AA via secretions from the body. The obligatory loss of AA occurs through hair, sweat, nasal secretions, menstruation (women), and seminal fluid (men), when a person is fed an essentially $\mathrm{N}$-free diet that meets energy requirements. The factorial method can be used only when data on AA oxidation in the whole-body or a tissue of interest are available, and is particularly useful for determining the dietary requirements of AA that are synthesized in mammalian cells.

\subsection{Tracer studies for determining dietary requirements of AA and protein}

The rate of oxidation of an AA depends on its concentration in the free pools (e.g., plasma and intracellular fluids), the nutritional status, and the physiological needs of the subject. ${ }^{1}$ As noted previously, excessive amounts of AA are generally not stored in the body and will be disposed of primarily via oxidation and urea synthesis in humans. An increase in the oxidation of an AA is usually an indicator of its excessive availability in the body, provided that there are no significant changes in the concentrations of regulatory hormones coenzymes, cofactors, or metabolites. ${ }^{21}$ In other words, if the supply of an AA exceeds its needs by the human, this AA is oxidized to $\mathrm{CO}_{2}$, water, ammonia, and urea (Fig. 2). In the direct AA oxidation method, oxidation of a test AA $\left(e . g ., \mathrm{L}-\left[1-{ }^{13} \mathrm{C}\right]\right.$ lysine) is determined to estimate its dietary requirement. In the indicator (indirect) AA oxidation method, oxidation of a different $\mathrm{AA}\left(\right.$ e.g. , $\mathrm{L}-\left[1-{ }^{13} \mathrm{C}\right]$ phenylalanine) than the test $\mathrm{AA}$ (e.g., proline) is determined to estimate the dietary requirement of the test AA. Since the early 1980s, the direct and indirect AA oxidation techniques have been used to determine the dietary requirements of many EAA by children and adults. ${ }^{11,12,21}$

\subsection{Lack of consideration of functional needs by humans in $\mathrm{N}$ balance and isotopic studies}

Each method for determining the dietary requirements of AA and protein has its own strengths and weaknesses. $\mathrm{N}$ balance measurement is a simple and relatively inexpensive approach to estimate the dietary requirements of AA and proteins by humans. The common advantages of both the direct and the indicator AA oxidation methods over the $\mathrm{N}$ balance technique are that: (a) the dietary requirements of AA can be estimated within a short period of time after several days of adaptation to experimental diets, without the need for a long, expensive stay (e.g., one week or longer) in a metabolic facility; and (b) changes in whole-body oxidation of a specific AA in response to different intakes of dietary AA or protein can be assessed. However, both $\mathrm{N}$ balance and isotope studies are only shortterm experiments, and do not take, into consideration, the functional needs of AA beyond protein synthesis in humans.

Let us use histidine and arginine as examples to illustrate some shortcomings of $\mathrm{N}$ balance studies. The results of the $\mathrm{N}$ balance studies by Rose did not reveal the dietary requirements of histidine or arginine by healthy adults. ${ }^{10}$ Explanations for the failure to identify histidine as an EAA are that: (a) hemoglobin contains a relatively large amount of histidine and breakdown of this protein yields histidine; and (b) skeletal muscle contains millimolar concentrations of histidine in the form of dipeptides (e.g., carnosine) and their hydrolysis provides histidine. Extending the experimental period of feeding a histidine-free diet from 8 to 28 days or longer substantially reduces the endogenous release of histidine from hemoglobin and intramuscular small peptides, thereby resulting in a negative $\mathrm{N}$ balance in adults. ${ }^{24,25}$ On the other hand, arginine was traditionally not considered as an EAA for healthy adults. ${ }^{26}$ However, feeding an arginine-deficient diet to adult men for 9 days decreased both the number and motility of sperm cells by $90 \%$ despite $\mathrm{N}$ balance at equilibrium. ${ }^{27}$ This striking observation underlines a critical role for arginine in spermatogenesis. In addition, extensive studies with pregnant dams have shown that dietary arginine is required for the optimal survival and growth of embryos and fetuses. ${ }^{28}$ These findings argue strongly that functional needs beyond protein synthesis and $\mathrm{N}$ balance should be important criteria for the dietary requirements of AA and proteins. Despite its shortcomings, the $\mathrm{N}$ balance approach remains an invaluable procedure for determining the dietary requirements of $\mathrm{AA}$ and proteins for humans.

\section{Recommended values of dietary requirements of $A A$ and proteins for humans}

\subsection{General considerations}

Metabolism of proteins in humans is closely related to that of energy, because AA transport, intracellular protein turnover, ammonia detoxification (via urea, uric acid and glutamine syntheses), formation of purines and pyrimidines, as well as renal reabsorption of AA and excretion of nitrogenous metabolites require energy. ${ }^{1}$ Physiological energy substrates from foods are fatty acids, glucose, and amino acids, which are primarily in the forms of triacylglycerol, starch, and protein, respectively. Therefore, consumption of dietary protein must be considered in the context of intake of other energy substrates. The use of AA as major metabolic fuels for tissues other than the small intestine and immune cells is not desirable because of their lower energetic efficiency, as compared with fatty acids and glucose. ${ }^{1}$ In addition, catabolism of many 
AA requires NADPH, which is generated primarily from glucose metabolism via the pentose cycle.

There is often confusion about either the energy value of protein or dietary protein intake as a percentage of energy intake in human nutrition. The gross calories of fat, protein, and starch, as determined in bomb combustion, are 9.4, 5.4, and $4.1 \mathrm{kcal} \mathrm{g}^{-1}$, respectively. The amounts of energy released from the oxidation of fat, protein, and starch to water and $\mathrm{CO}_{2}$ in vivo are 9.4, 4.1, and $4.1 \mathrm{kcal} \mathrm{g}^{-1}$, respectively. Because not all dietary fat, protein, and starch are digested in stomach and the small intestine, and because protein oxidation in the body is incomplete, the physiological values of energy in dietary fat, protein, and starch for humans are usually taken to be 9, 4, and $4 \mathrm{kcal} \mathrm{g}^{-1}$, respectively. The resting metabolic rate (RMR) of healthy humans, expressed as kcal per $\mathrm{kg}$ BW per day, decreases with age, ranging from $55 \mathrm{kcal}$ per $\mathrm{kg}$ BW per day in the 5 -year-old to $25 \mathrm{kcal}$ per $\mathrm{kg}$ BW per day in the 45 -year-old. ${ }^{29}$ Because of energy requirements for physical activity (e.g., walking, lifting, and doing home chore) beyond rest, free-living individuals should have dietary energy intake above their RMR. For example, a 45-year-old adult with minimum physical activity would need $30 \mathrm{kcal}$ energy per $\mathrm{kg}$ BW per day $(1.2 \times \mathrm{RMR}){ }^{29}$

The dietary requirements of AA and protein are affected by: (a) dietary factors (e.g., AA content and proportions, energy intake, presence or absence of other substances, and food processing); (b) physiological characteristics of subjects (e.g., age, sex, genetic backgrounds, circadian clock, hormones, pregnancy, lactation, and physical activity); (c) pathological states (e.g., infection, trauma, neoplasia, diabetes, obesity, cardiovascular disease, and fetal growth restriction); and (d) environmental factors (e.g., temperatures, toxic agents, air pollution, dietary habits, sanitation, and personal hygiene). These factors should be taken into consideration in estimating the human requirements for dietary $\mathrm{AA}^{30-32}$

\subsection{Healthy humans with minimum physical activity}

Based on the meta-analysis of short-term $\mathrm{N}$ balance studies in humans, ${ }^{33}$ the Recommended Dietary Allowance (RDA) of protein for a healthy adult with minimal physical activity is currently $0.8 \mathrm{~g}$ protein per $\mathrm{kg}$ BW per day (Table 1 ). For comparison, values for infants and children are greater because they grow and gain protein. Dietary protein is assumed to be of high quality (a typical mixture of animal- and plant-source proteins) with a biological value of $75 \%$ (efficiency with which a truly digestible protein is utilized for maintenance and protein deposition in the body). Values on percentages of dietary energy from proteins (e.g., dietary protein contributing to 10 to $35 \%$ of total dietary energy; e.g., $120 \mathrm{~kJ}$ per kg BW per day for 31- to 50-year-old men with minimal physical activity) should not be used out of context without the consideration of total daily caloric intake. These data translate into 0.75 to $2.63 \mathrm{~g}$ protein per $\mathrm{kg}$ BW per day for a healthy adult who has minimum physical activity. As suggested previously, ${ }^{34}$ functional needs (e.g., support of spermatogenesis, fetal survival and growth, blood circulation, resistance to infectious disease, as well as skeletal muscle mass and health) should also be an
Table 1 Dietary protein requirements by humans of all age groups

\begin{tabular}{|c|c|c|c|c|}
\hline \multirow[b]{3}{*}{ Group } & \multirow[b]{3}{*}{ Age (years) } & \multicolumn{3}{|c|}{$\begin{array}{l}\text { Dietary requirements of protein } \\
\text { (g per kg body weight per day) }\end{array}$} \\
\hline & & \multirow{2}{*}{$\begin{array}{l}\mathrm{IOM}^{a} \\
2005\end{array}$} & \multicolumn{2}{|c|}{$\mathrm{FAO} / \mathrm{WHO} / \mathrm{UNU}^{b}$} \\
\hline & & & 1985 & 2007 \\
\hline \multirow[t]{2}{*}{ Infants } & $0.3-0.5$ & 1.52 & 1.75 & 1.31 \\
\hline & $0.75-1.0$ & 1.50 & 1.57 & 1.14 \\
\hline \multirow[t]{2}{*}{ Children } & $1-3$ & 1.10 & 1.18 & 1.02 \\
\hline & $4-8$ & 0.95 & 1.05 & 0.92 \\
\hline \multirow[t]{3}{*}{ Adolescents } & $9-13$ & 0.95 & 0.99 & 0.90 \\
\hline & 14-18 (boys) & 0.85 & 0.97 & 0.87 \\
\hline & $14-18$ (girls) & 0.85 & 0.94 & 0.85 \\
\hline Adults & $\geq 19$ & 0.80 & 0.75 & 0.83 \\
\hline
\end{tabular}

${ }^{a}$ Recommended dietary allowance (RDA) published by the Institute of Medicine. ${ }^{26}{ }^{b} \mathrm{FAO} / \mathrm{WHO} / \mathrm{UNU}$ (World Health Organization/Food and Agriculture Organization/United Nations University). ${ }^{22}$

important criterion to recommend dietary AA and protein requirements for humans. There are reports that consumption of 25 to $30 \mathrm{~g}$ high-quality protein ( 0.333 to $0.40 \mathrm{~g}$ per $\mathrm{kg} \mathrm{BW}$ ) and adequate energy in a single meal maximally stimulates skeletal-muscle protein synthesis in the resting $75 \mathrm{~kg}$ young adult man. ${ }^{35,36}$ This translates to 75 to $90 \mathrm{~g}$ protein for a 25-30 $\mathrm{g}$ of protein per meal for 3 meals daily $(1.0$ to $1.2 \mathrm{~g}$ per $\mathrm{kg}$ BW per day). Of note, an increase in skeletal-muscle protein synthesis occurs within 1-2 h after consumption of dietary protein or AA and is sustained for $3 \mathrm{~h}$ thereafter. ${ }^{37,38}$

Recent studies have shown that the $\mathrm{N}$ balance-based estimates of dietary AA requirements by humans are considerably lower than the values obtained by the AA oxidation methods. The differences can be up to 2- to 3-fold for many EAA (Table 2). These discrepancies may result from both methodological and physiological factors. In all the various versions of recommended AA requirements, only EAA are considered and represent only $8-27 \%$ of the RDA. This is clearly a limitation, as synthesizable AA are more abundant than EAA in tissues (e.g., skeletal muscle) and can limit protein synthesis in skeletal muscles. ${ }^{39-41}$ The original $\mathrm{N}$ balance experiments may overestimate $\mathrm{N}$ retention due to methodological reasons, therefore underestimating dietary AA requirements. On the other hand, the use of tracers in metabolic research has potential problems associated with label dilution, isotope exchange, determination of intracellular specific activities of immediate precursors, and isotopic steady states. ${ }^{1}$ New knowledge about AA biochemistry and nutrition, as well as improved methodologies for studying whole-body AA metabolism, will be necessary to resolve the current dispute on the dietary requirement of AA by humans. Additionally, considerations should be given to dietary requirements of synthesizable AA. ${ }^{41}$ Based on the dietary requirements of protein and lysine by humans, as well as the ratios of lysine to synthesizable AA in diets for pigs (excellent animal models for studying human nutrition), ${ }^{42}$ the recommended requirements of the so-called "nutritionally nonessential AA" for infants, children and adults are given 
Table 2 Dietary requirements of EAA by healthy human adults

\begin{tabular}{|c|c|c|c|c|c|}
\hline \multirow[b]{2}{*}{ EAA } & \multicolumn{2}{|c|}{$\begin{array}{l}\text { Estimates from } \\
\mathrm{N} \text { balance } \\
\text { experiments }^{a}\end{array}$} & \multirow{2}{*}{$\begin{array}{l}\text { MIT values }^{a} \\
\text { (tracer studies) } \\
(2000)\end{array}$} & \multirow{2}{*}{$\begin{array}{l}\mathrm{IOM}^{b} \\
(2005)\end{array}$} & \multirow{2}{*}{$\begin{array}{l}\mathrm{FAO} / \mathrm{WHO} / \\
\mathrm{UNU}^{c}(2007)\end{array}$} \\
\hline & $\operatorname{Men}^{d}$ & Women $^{e}$ & & & \\
\hline & & & \multicolumn{3}{|c|}{ mg per kg body weight per day } \\
\hline His & - & - & - & 14 & 10 \\
\hline Ile & 10 & 9.17 & 23 & 19 & 20 \\
\hline Leu & 15.7 & 12.1 & 40 & 42 & 39 \\
\hline Lys & 11.4 & 9.07 & 30 & 38 & 30 \\
\hline Met & 2.36 & 3.23 & - & - & - \\
\hline Met + Cys & 15.7 & 11.7 & 13 & 19 & 15 \\
\hline Phe & 4.29 & 4.30 & - & - & - \\
\hline Phe + Tyr & 15.7 & - & 39 & 33 & 25 \\
\hline Thr & 7.14 & 6.25 & 15 & 20 & 15 \\
\hline Trp & 3.57 & 2.80 & 6 & 5 & 4 \\
\hline Val & 11.4 & 10.4 & 20 & 24 & 26 \\
\hline Total & 90.6 & 65.8 & 186 & 214 & 184 \\
\hline
\end{tabular}

${ }^{a}$ Adapted from Young and Borgonha. ${ }^{20}{ }^{b}$ Recommended dietary allowance (RDA) published by the Institute of Medicine (IOM). ${ }^{26}{ }^{c} \mathrm{FAO} /$ WHO/UNU (World Health Organization/Food and Agriculture Organization/United Nations University, 2007). ${ }^{22}{ }^{d}$ Body weight = $70 \mathrm{~kg}$. ${ }^{e}$ Body weight $=60 \mathrm{~kg}$. MIT $=$ Massachusetts Institute of Technology.

in Table 3. These values are expected to provide a muchneeded database for future research on human protein nutrition.

The RDA represents only minimum daily average dietary intake that meets the nutrient requirements of nearly all (97.5\%) healthy individuals in a particular life stage. ${ }^{26}$ As noted previously, the RDA of a protein was recommended to meet $\mathrm{N}$ balance, and should not be considered as the optimal amount for maintenance, optimal health or specific functions of organs. In this regard, it is noteworthy that skeletal muscle is the major reservoir of $\mathrm{AA}$ in the body and undergoes decreases in both mass and physical strength with aging. Several lines of evidence show that the current RDA of protein is insufficient for adult humans with minimum physical activity. First, elderly adults who consumed diets providing $0.8 \mathrm{~g}$ protein per $\mathrm{kg}$ BW per day for 14 weeks lost skeletal- muscle mass. ${ }^{43}$ Second, men and women (70-79 years of age) lost the most amount of skeletal muscle during a 3-year period when they consumed the lowest amount of dietary protein $\left(\leq 0.8 \mathrm{~g}\right.$ protein per $\mathrm{kg}$ BW per day). ${ }^{44}$ Third, increasing dietary protein intake moderately above the RDA by $25-35 \%$ enhanced muscle protein anabolism and reduced the progressive loss of muscle weight in adults with advanced age. ${ }^{43-45}$ Thus, adequate protein intake is highly beneficial for healthy aging.

\subsection{Healthy humans with moderate or intense physical activity}

A sedentary lifestyle has a profound negative effect on skeletal muscle. For example, a 7-day bed rest in young healthy males can decrease leg muscle mass by $3 \%$ and muscle $\mathrm{O}_{2}$ consumption by $4 \% .{ }^{46}$ Much evidence shows that moderate exercise is beneficial for improving skeletal muscle mass as well as muscle and whole-body health, while reducing the risk of metabolic syndrome. ${ }^{32}$ Of interest, improvement in the sensitivity of myofibrillar protein synthesis to AA supply can persist for up to $24 \mathrm{~h}$ after resistance exercise. ${ }^{47}$ Even in the elderly, resistance exercise (e.g., weight-lifting) can enhance skeletalmuscle mass and strength. ${ }^{48}$ Indeed, dietary protein and moderate exercise have synergistic effects on skeletal-muscle protein synthesis. Thus, American College of Sports Medicine (ACSM) has recommended strength training for the elderly to sustain muscle mass and function. ${ }^{49}$

During exercise, there is a negative balance between the rates of protein synthesis and breakdown in the whole body, as well as an increase in the rate of whole-body AA oxidation, resulting in a transient catabolic state. ${ }^{50,51}$ The underlying mechanisms differ with the type of exercise in that exhaustive endurance exercise reduces the rate of protein synthesis without affecting protein breakdown in the whole body (including skeletal muscle). ${ }^{52}$ In contrast, a prolonged bout of resistance exercise results in an increase in the rate of protein breakdown in the whole body (including skeletal muscle) being greater than an increase in the rate of protein synthesis. ${ }^{52}$ The magnitudes of these changes also depend on the type of exercise. Even moderate exercise (e.g., $1 \mathrm{~h}$ treadmill exercise at $55 \%$ of $\mathrm{VO}_{2} \max$ ) stimulates whole-body protein catabolism by $25 \%$ in a healthy

Table 3 Recommended dietary requirements of "nutritionally nonessential amino acids" for healthy humans ${ }^{a}$

\begin{tabular}{|c|c|c|c|c|c|c|c|c|c|c|c|c|c|c|}
\hline \multirow[b]{2}{*}{ Group } & \multicolumn{2}{|l|}{$\mathrm{EAA}^{b}$} & \multicolumn{12}{|c|}{ Nutritionally nonessential amino acids (NEAA) } \\
\hline & Total & Lys & Total & Ala & Arg & Asn & Asp & Cys & Glu & Gln & Gly & Pro & Ser & Tyr \\
\hline Infants $^{c}(0.3$ to $1 \mathrm{y})$ & 402 & 71.3 & 1098 & 69.2 & 71.3 & 48.6 & 69.2 & 21.6 & 121 & 108 & 76.7 & 82.1 & 42.2 & 39.9 \\
\hline Children $^{d}$ ( 1 to $3 y$ ) & 295 & 52.3 & 805 & 50.7 & 52.3 & 35.6 & 50.7 & 15.8 & 88.7 & 79.2 & 56.2 & 60.2 & 30.9 & 29.3 \\
\hline \multicolumn{15}{|l|}{ Adults (>18 y) } \\
\hline Minimal PA & 268 & 47.5 & 732 & 46.1 & 47.5 & 32.4 & 46.1 & 14.4 & 80.6 & 72.0 & 51.1 & 54.7 & 28.1 & 26.6 \\
\hline Moderate PA & 348 & 61.8 & 952 & 60.0 & 61.8 & 42.1 & 60.0 & 18.7 & 105 & 93.6 & 66.4 & 71.1 & 36.5 & 34.6 \\
\hline Intense PA & 429 & 76.0 & 1171 & 73.8 & 76.0 & 51.8 & 73.8 & 23.0 & 129 & 115 & 81.8 & 87.5 & 45.0 & 42.6 \\
\hline
\end{tabular}

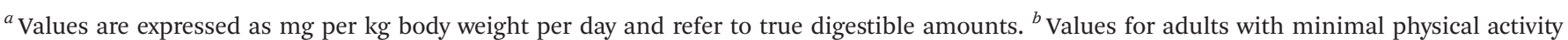

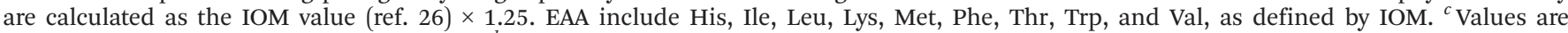
calculated as $1.5 \times$ adult value (minimal PA). ${ }^{d}$ Values are calculated as $1.1 \times$ adult value $($ minimal PA). PA $=$ physical activity; $y=y e a r$. 
adult. ${ }^{53}$ This translates into the dietary protein requirement of $\geq 1 \mathrm{~g}$ per kg BW per day. Unless sufficient dietary protein is consumed during recovery for increased synthesis of muscle proteins, protein degradation will exceed protein synthesis, resulting in a loss of muscle mass and negative $\mathrm{N}$ balance. In support of this view, healthy adults who performed intensive exercise daily (9.9 kcal $\mathrm{min}^{-1}$ for 6 of $20 \mathrm{~min}$ periods) for 3 weeks and consumed $1 \mathrm{~g}$ protein per $\mathrm{kg}$ BW per day exhibited negative $\mathrm{N}$ balance during each day of the training program. ${ }^{51}$

When the dietary intake of AA and energy is sufficient during a prolonged post-exercise period of recovery, a positive protein balance occurs in the whole body (including skeletal muscle). ${ }^{54}$ For example, in adequately fed subjects, the rates of muscle protein synthesis were increased by $112 \%, 65 \%$, and $34 \%$ at 3, 24 and $48 \mathrm{~h}$ post exercise, respectively, whereas the rates of muscle protein breakdown were increased by $31 \%$ and $18 \%$ at 3 and $24 \mathrm{~h}$ post exercise, respectively, and returned to resting levels by $48 \mathrm{~h}^{55}$ The effective time period for an anabolic response can last for up to $48 \mathrm{~h}$ after a single workout. ${ }^{56}$ The underlying molecular mechanisms involve: (a) the improved sensitivity of tissues (particularly skeletal muscle) to insulin and the activation of the mTOR signaling to stimulate protein synthesis ${ }^{57}$ and (b) activated autophagy to promote proteolysis. ${ }^{58}$ In healthy adult men with moderate physical activity (90 min on a cycle ergometer at $45-50 \%$ of maximal $\mathrm{O}_{2}$ uptake two times daily), frequent consumption of small meals providing $2.5 \mathrm{~g}$ protein per $\mathrm{kg}$ BW per day resulted in a positive whole-body protein balance, compared with a protein intake of $1 \mathrm{~g}$ per kg BW per day. ${ }^{59}$ Thus, the net effect of exercise on muscle protein accretion critically depends on sufficient provision of dietary AA and energy. In adequately fed subjects, the overall chronic responses of protein metabolism to regular exercise are anabolic and beneficial for inducing skeletalmuscle hypertrophy, improving muscle protein-mass and function, and preventing muscle wasting. ${ }^{60}$

Recently, ACSM, the American Dietetic Association, and Dieticians of Canada recommended that endurance-training (moderate exercise) athletes and strength-training (intense exercise) athletes consume 1.3 (ranging from 1.2 to 1.4) and 1.6 (ranging from 1.2 to 1.7 ) g protein per $\mathrm{kg}$ BW per day, respectively. ${ }^{49}$ A combination of whey (a rapidly digested protein) with casein (a slow digested protein) seems to be an effective formula for skeletal-muscle protein synthesis after exercise. There is evidence that the inclusion of high-quality animal protein or combinations of high-quality plant-based proteins can stimulate muscle anabolism. ${ }^{61}$ Recent data also indicate that adequate intake of protein at each meal of the day has an advantage over a large amount of protein in a single meal to support skeletal-muscle mass and function. ${ }^{48}$

Timing of protein or AA consumption is important for muscle recovery after exercise. Skeletal muscle takes up nutrients (e.g., $\mathrm{AA}$, glucose and fatty acids) from the blood circulation most efficiently within the first 30-60 min after an exercise program is completed, followed by great reductions several hours later. ${ }^{32}$ Thus, the response of muscle protein synthesis to exercise-induced anabolism is much greater when AA intake is initiated immediately after the end of exercise, as compared to $3 \mathrm{~h}$ after the end of exercise. ${ }^{62}$ As noted previously, the proportions and amounts of all AA in diets should be considered when specific EAA are supplemented to subjects after exercise. For example, consuming individual branchedchain AA (BCAA) alone cannot enhance muscle protein synthesis when the availability of other AA is limited. ${ }^{63}$ This is because protein synthesis requires all 20 different AA as the building blocks.

\subsection{Obese humans on a weight-reducing program}

Through metabolites and cell signaling, AA play an important role in regulating the oxidation of fatty acids and glucose in a cell- and tissue-specific manner. ${ }^{5}$ For example, enzymes of metabolic pathways are synthesized from AA. Second, the physiological levels of NO (a product of arginine catabolism) enhance the oxidation of fatty acids and glucose to $\mathrm{CO}_{2}$ and water. ${ }^{64}$ Third, the physiological levels of glutathione (formed from cysteine, glycine and glutamate), taurine (a metabolite of methionine), glycine, proline, and hydroxyproline (derived from proline) protect cells and tissues from oxidative injury and inflammation. ${ }^{65}$ Fourth, thyroid hormones (derived from tyrosine) are required to maintain adequate rates of basal energy metabolism in humans. ${ }^{66}$ Fifth, creatine (formed from arginine, glycine, and methionine) is needed to store energy as phosphocreatine for muscular work and neurological function. ${ }^{67}$ Six, carnitine (synthesized from lysine, methionine and serine) is required to transport long-chain fatty acids from the cytoplasm into the mitochondrion for $\beta$-oxidation to yield acetyl-CoA. ${ }^{1}$ Seventh, serotonin and melatonin (metabolites of tryptophan) inhibit the production of inflammatory cytokines to maintain the health of adipose tissue, while regulating food intake and behavior by humans. ${ }^{39}$ Finally, arginine, leucine, glycine, tryptophan and glutamine activate the mTOR signaling pathway to stimulate skeletal-muscle protein synthesis, ${ }^{41}$ thereby partitioning dietary energy from the fat stores into muscle building.

Thus, it is clear that a combination of physical activity and increased intake of high-quality protein provides an effective strategy to enhance fat loss and improve metabolic profiles in obese subjects. In the well-controlled study of Layman et al., ${ }^{60}$ obese women in a 16-week weight-loss program were assigned to various intensities of exercise and protein intake levels. The authors found that subjects in the high protein-exercise group lost $3 \mathrm{~kg}$ body fat without a loss of lean body mass, whereas subjects in the low protein-exercise group lost both white fat and skeletal muscle. ${ }^{60}$ Similarly, Josse et $a{ }^{68}{ }^{68}$ reported that combining exercise training with a higher protein intake (mainly derived from dairy foods) resulted in the loss of body fat and preservation of muscle mass. Augmenting dietary provision of proteins can increase the circulating levels of arginine, which enhances insulin sensitivity, stimulates the oxidation of fatty acids and glucose in skeletal muscle, promotes whole-body energy expenditure, and reduces white-fat mass in obese humans. ${ }^{69}$ Furthermore, in free-living subjects, adequate consumption of dietary protein can have a satiety 
effect and, therefore, reduce food or energy intake by inhibiting the release of ghrelin (an appetite-promoting polypeptide) and stimulating the release of peptide YY and glucagonlike peptide 1 (appetite-suppressing polypeptides). ${ }^{70}$ These changes in the endocrine status help to control white-fat gains and preserve skeletal-muscle mass in a long-term, sustainable manner. On top of habitual protein intake (e.g., $1.07 \mathrm{~g}$ per $\mathrm{kg}$ BW per day in US adults), additional consumption of $0.31 \mathrm{~g}$ protein per $\mathrm{kg}$ BW per day to achieve an intake of $1.38 \mathrm{~g}$ protein per kg BW per day is beneficial for long-term management of BW to minimize white adipose tissue and maximize skeletal-muscle mass. ${ }^{70}$ In healthy adults, dietary protein is used to primarily support intracellular synthesis of polypeptides and low-molecular-weight bioactive substances. ${ }^{1}$ Thus, only $8 \%$ of dietary protein is used for gluconeogenesis, and the remainder for the maintenance of whole-body protein turnover and tissue-specific AA oxidation in humans. ${ }^{71}$

\subsection{Frequency of meals}

Humans usually eat breakfast, lunch and dinner at regular times of the day (e.g., 7:00 AM, 12:00 noon, and 7:00 PM). Thus, the recommended values of dietary requirements of AA and proteins are intended for three meals in a day. This should apply to both athletes and non-athlete adults, as well as growing children. The rate of skeletal-muscle protein synthesis in healthy adults is $25 \%$ higher when protein intake is evenly distributed across breakfast, lunch, and dinner, compared with a pattern where most protein is consumed at the evening meal despite the same daily intake of total protein. ${ }^{72}$ This finding has important implications for improving skeletal-muscle mass, strength and function in older, physically active adults who generally experience a resistance to the stimuli of muscle protein synthesis and have a higher threshold of dietary protein intake to promote muscle protein synthesis.

\section{Quality of dietary protein}

\subsection{Higher protein nutritional value of animal- than plant- source proteins for humans}

Both animal and plant products are excellent sources of select vitamins (e.g., vitamin B12 from meat and folate from green leafy vegetables), whereas animal products generally provide more biologically available minerals than plant products. ${ }^{30}$ The Food and Agriculture Organization proposed the use of the Protein Digestibility Corrected Amino Acid Score (PDCAAS) $^{22}$ and, more recently, the Digestible Indispensable Amino Acid Score ${ }^{7}$ to assess the quality of dietary protein. However, both the PDCAAS and DIAAS indexes ignore: (a) physiological needs of EAA for tissue (e.g., skeletal muscle) protein synthesis or function, and (b) the important roles of synthesizable AA in human nutrition and metabolism. Animal-source foods (e.g., meat, dairy products, egg, poultry, seafood, and other products) contain higher quantities and more balanced proportions of AA relative to human tissues, than plant-source foods (e.g., rice, wheat, corn, potato, vegetables, cereals, beans, peas, processed soy products, nuts, and seeds). ${ }^{7,73}$ For example, beef meat contains $63-68 \%$ protein on the dry matter basis, but most staple foods of plant origin (except for legumes) have a protein content $<12 \%$ (dry matter basis) and are deficient in most AA, including lysine, methionine, cysteine, tryptophan, threonine, and glycine. ${ }^{74}$ To meet the Institute of Medicine-recommended dietary allowance of methionine plus cysteine by the $70 \mathrm{~kg}$ adult human, daily intake of meat, wheat flour, or rice would be 45, 285, or $493 \mathrm{~g}$ dry matter, respectively. The excessive amount of carbohydrates that would be consumed in the wheat flour or rice can be converted into fat in the body, thereby contributing to development of obesity, dyslipidemia, and other metabolic disorders. Based on this calculation, consumption of meat can substantially reduce the need for plant-based foods to meet adequate AA requirements of humans. ${ }^{30}$ Importantly, meat is a rich source of both taurine (a sulfur-containing AA essential for protecting the eyes, heart, skeletal muscle, and other tissues of humans from oxidative damage and degeneration) and carnosine (an antioxidant dipeptide that maintains neurological and muscular functions). ${ }^{1}$ of note, plants do not contain taurine or carnosine. ${ }^{1}$ Additionally, protein in animal products has a higher digestibility $(\sim 95 \%)$ than proteins isolated from plants $(\sim 85-92 \%)$ or proteins in whole plant foods $(\sim 80-85 \%)$ which generally contain anti-nutritional factors. ${ }^{3}$

Several lines of evidence show that animal-source protein has a greater nutritional value than plant-source protein to sustain skeletal-muscle mass. First, dietary supplementation of $17.5 \mathrm{~g}$ milk protein per day during a 12-week resistance exercise program increased lean body mass (3.9 vs. $2.8 \mathrm{~kg}$ ) than an isonitrogenous amount of soy protein. ${ }^{75}$ Second, compared with soy protein, dietary supplementation with $24 \mathrm{~g}$ whey per day to young men enhanced their lean tissue gains (3.3 vs. $1.8 \mathrm{~kg}$ ) after 36 weeks of resistance exercise training. ${ }^{76}$ Third, ingestion of animal-source protein by healthy adults ranging from 17.5 to $40 \mathrm{~g}$ from whey, skimmed milk, or beef stimulated skeletal-muscle protein synthesis to a greater extent than the same amount of soy protein under resting and post-exercise conditions. $^{61}$ Fourth, long-term vegetarianism resulted in reduced skeletal-muscle mass in older women, compared with consumption of an omnivorous diet (18.2 vs. $22.6 \mathrm{~kg}$ lean body mass). ${ }^{77}$ Thus, as a nutritional strategy, adequate consumption of animal protein (e.g., nutrient-dense lean meat) can reverse the decline in protein intake by adults in the age groups of $\geq 51$ years. This simple means is vitally important for sustaining skeletal-muscle mass and improving health in aging adults.

\subsection{Differential nutritional values of animal-source proteins}

The nutritional quality of animal-source food proteins is not equal even though they are all highly digestible in the human gastrointestinal tract. For example, whey is often considered to be better than casein for muscle builders consuming protein powder after exercise. ${ }^{76}$ The possible reasons are as follows. First, whey protein has a higher content of arginine, leucine, lysine, and sulfur-containing AA (methionine and cysteine) 
than casein. Second, individual AA are released more rapidly from whey protein (a "fast-release" protein digested within $1 \mathrm{~h}$ ) than casein (a "slow-release" protein) in the small intestine to support muscle protein synthesis immediately after exercise. Thus, consumption of whey protein stimulated postprandial muscle protein accretion more effectively than casein or casein hydrolysate in elderly men. ${ }^{78}$ In addition, when supplemental whey protein ( $0.15 \mathrm{~g}$ protein per $\mathrm{kg}$ BW per day) was consumed for 24 weeks by postmenopausal women immediately after weight training, skeletal-muscle strength was consistently improved by $9 \% .^{79}$ In contrast, inconsistent results (including no change) in muscle strength were reported for elderly men who consumed a casein supplement (20 g per session; 3 sessions per week) immediately before and after resistance training. ${ }^{80}$ However, it is unknown whether such a pattern of casein supplementation is sufficient to sustain elevated levels of AA in the plasma to stimulate muscle protein synthesis.

\subsection{Appropriate proportions of animal- vs. plant-source proteins in nutrition}

An ideal human diet would consist of both animal- and plantsource foods in appropriate amounts and proportions to ensure intake of sufficient quantity and quality of proteins, while consuming adequate dietary fiber. ${ }^{30}$ Globally, plant- and animal-based foods contribute $\sim 65 \%$ and $35 \%$ of protein, respectively, in human diets, and the opposite is true in North America. ${ }^{30}$ While proper combinations of large amounts of legumes with cereals could provide sufficiently most AA, the global availability of legumes as a staple food is increasingly limited and in many parts of the world, these foods are not produced. ${ }^{81}$ At best, such combinations may meet protein requirements of adults with minimal physical activity but not for optimal growth or development in children. In homebound elderly subjects, consuming $<65 \%$ of total protein from animal-source foods results in the deficiency of at least one EAA, leading to protein undernutrition. ${ }^{8}$ In any case, assessment of dietary protein quality solely on the basis of ratios of EAA to lysine without consideration of the total content of protein and its digestibility is potentially misleading. Appropriate proportions of animal- $v s$. plant-source proteins in diet should provide sufficient EAA and synthesizable AA, as well as their optimal ratios relative to lysine (Tables 2 and 3).

\section{Protein deficiency in humans and its amelioration by intake of animal protein}

\subsection{Global perspectives of protein deficiency in humans}

Currently, about one billion people (including 165 million children under 5 years of age) worldwide have chronic inadequate intake of protein. ${ }^{30}$ In central Africa and South Asia, up to $30 \%$ of children have protein malnutrition. ${ }^{74}$ Protein deficiency also occurs in subpopulations in developed nations. For example, $51 \%$ of home-bound elderly subjects receiving home-delivered meals in the United States have a protein intake below the RDA of $0.8 \mathrm{~g}$ protein per $\mathrm{kg}$ BW per day. Additionally, $25 \%$ to $85 \%$ of patients in long-term care facilities have protein undernutrition. ${ }^{82}$ Furthermore, cancer patients lose tremendous amounts of protein due to low food intake, impaired digestion, and increased catabolism. ${ }^{83}$ Globally, protein-energy undernutrition accounts for 6 million deaths annually. ${ }^{74}$ The number of people with protein deficiency could increase substantially, as the United Nations projected in June 2013 that the world population will reach from the current 7.2 billion to 8.2 billion by 2025 and to 9.6 billion by $2050 .^{84}$

\subsection{Health consequences of protein deficiency in humans}

Protein deficiency causes multiple clinical syndromes, ${ }^{85}$ which are summarized in Table 4. This nutritional problem can occur in any community at any age due to illness or poor diets, and is frequently exacerbated by inadequate energy intake. ${ }^{22}$ Dietary protein deficiency not only contributes to poor growth, cardiovascular dysfunction, and high risk of infectious disease, but also exacerbates the deficiency of other nutrients (including vitamin A and iron) and worsens metabolic profiles (e.g., dyslipidemia and hyperglycemia) in humans. This is because of the need for protein to: (a) digest and absorb dietary nutrients by the small intestine; (b) transport nutrients (including long-chain fatty acids, vitamin A, and iron) and

Table 4 Symptoms of protein deficiency in humans

Decrease in protein synthesis and increase in proteolysis in skeletal muscle and whole body

Low serum albumin; reduced concentrations of amino acids in plasma Endocrine imbalance; reduced levels of insulin, growth hormone, IGF-I, and thyroid hormones in plasma

Impaired anti-oxidative reactions; increased oxidative stress; advanced aging

Growth stunting of the young; impaired development (including cognitive development) of the young

Intrauterine growth restriction in maternal protein deficiency and its life-long negative consequences in postnatal growth, metabolism and health (e.g., increasing risk of obesity, infection, and cardiovascular abnormalities)

Impairments in absorption, transport and storage of nutrients (including vitamins, minerals, amino acids, glucose, and fatty acids)

Anemia, reduced transport of oxygen, reduced whole-body energy expenditure

Skeletal muscle wasting; physical fatigue; weakness; headache; fainting Impaired immune response; frequent infections; increased rates of morbidity and mortality from infectious diseases

Cardiac failure; cardiovascular abnormalities; hypertension Tissue fluid retention; peripheral and periorbital edema (particularly swelling in the abdomen, leg, hands, and feet)

Reduced synthesis of neurotransmitters; emotional disorders (e.g., moodiness, severe depression, and anxiety); irritability; insomnia Loss of libido; reduced fertility; embryonic loss

Loss of calcium and bones; dental abnormalities

Hair breakage and loss; reduced production of pigments; appearance of grey hair color

Pale skin; dry or flaking skin; skin atrophy 
other molecules (e.g., cholesterol and triacylglycerols) in blood; and (c) oxidize nutrients (including fatty acids and glucose) to water and $\mathrm{CO}_{2}{ }^{86-88}$ Thus, the deficiency of protein and micronutrients (including vitamin A, iron, zinc, and folate) remains a major nutritional problem in poor regions of the world. A severe deficiency of an AA can cause death, as indicated by inadequate provision of arginine in infants. ${ }^{1}$

Inadequate protein intake during gestation and postnatal periods has far-reaching adverse consequences in humans through mechanisms involving fetal and neonatal programming. ${ }^{5}$ This nutritional problem results in not only impaired growth of fetuses and infants, but also high risk of metabolic syndrome (including hypertension, obesity, and diabetes) and low quality of life as adults. ${ }^{1}$ Of particular interest, stunting in boys and girls will have serious negative effects on society and human physical strength, as well as the health (including reproductive health) of affected individuals and their generations of offspring. ${ }^{31}$ In the elderly population, protein undernutrition will exacerbate sarcopenia and further compromise skeletal-muscle functions. ${ }^{30}$

\subsection{Means to prevent protein deficiency in humans}

As noted previously, the quantity and quality of proteins are determinants of the adequacy of diets to meet human AA requirements. Consumption of animal-based foods (e.g., lean beef) is a simple and effective means to ameliorate the impairment of growth and development in millions of children worldwide. For example, Grillenberger $e t$ al. ${ }^{89}$ reported that, in 7-year-old children in Kenya who consumed basal diets (7300 kJ per day) consisting of almost exclusively staple crops (corn and beans) that met energy requirement, isocaloric supplementation (1050-1255 kJ per day) with meat improved growth and cognitive development. Of particular note, supplementation with animal protein increased upper arm muscle area by $80 \%$ in Kenyan children, compared with the control group. Similarly, in China, as consumption of animalsource foods increased by $115 \%$ between 1990 and 2010, the prevalence of growth stunting in children under 5 years of age decreased from $33 \%$ in 1990 to $9.5 \%$ in $2010 .{ }^{74}$ Furthermore, in low-income countries, consumption of milk and other animalsource foods by undernourished children improved anthropometric indices, while reducing morbidity and mortality. ${ }^{90}$ Consumption of animal protein as $\geq 65 \%$ of total dietary protein can prevent protein deficiency in elderly subjects. ${ }^{8}$ These findings indicate that plant proteins alone may not be adequate to support maximal growth and development in infants and children or optimize health in adults.

\section{Safe (tolerable) upper limits of dietary protein intake by humans}

\subsection{General considerations}

Safe (tolerable) upper limits for dietary protein intake (maximum safe intake) by young and adult humans have not been established, and can differ among individuals. Like any nutrient, divided protein intake at different meals of the day is preferred to reduce a sudden excess of any AA in the gastrointestinal tract, liver, brain, heart, kidneys, and other tissues. As noted previously, the Institute of Medicine recommended an acceptable macronutrient distribution range for protein intake at $10 \%$ to $35 \%$ of total energy for adults. It should be borne in mind that the dietary intake of energy should not exceed requirements and that the safety of protein intake is influenced by consumption of carbohydrates and lipids. In view of large variations among people in any age population, caution must be exercised not to adopt "one shoe fits all" guidelines when establishing safe upper limits of dietary protein intake by humans.

\subsection{Safe upper limits of dietary protein intake by infants and children}

The results of dietary surveys indicate that protein intake by infants during the complementary feeding period in industrialized countries is generally 2 to 3 times the RDA. For example, in the 1997 Copenhagen Cohort Study, the median protein intake of 12-month-old weaned infants in Denmark was $3.2 \mathrm{~g}$ per $\mathrm{kg}$ BW per day (14\% of energy intake) and the 90th percentile was $4.7 \mathrm{~g}$ per $\mathrm{kg}$ BW per day (18\% of energy intake). ${ }^{91}$ The mean protein intake of 9 to 12 month-old infants in other industrialized European countries was even higher than that from the Copenhagen Cohort Study, with the highest value being in Italy where the mean intake of protein was $5.1 \mathrm{~g}$ per $\mathrm{kg}$ BW per day (19.5\% of energy intake). ${ }^{92}$ In healthy older (2.5-year-old) Danish children, the 10th, 50th, and 90th percentiles of dietary protein intake were 2.4, 2.9, and $4.0 \mathrm{~g}$ per $\mathrm{kg} \mathrm{BW}$ per day, respectively, with $63 \%$ of the dietary protein being derived from animal-source foods. ${ }^{93}$ These data indicate that healthy 1- to 3-year-old children can tolerate a dietary intake of $5 \mathrm{~g}$ protein per $\mathrm{kg}$ BW per day (Table 5 ).

\subsection{Safe upper limits of dietary protein intake by adults}

Healthy adults can tolerate long-term consumption of $2 \mathrm{~g}$ dietary protein per $\mathrm{kg}$ BW per day $^{32}$ or even a higher amount. ${ }^{94-97}$ For example, consumption of $3 \mathrm{~g}$ dietary protein per kg BW per day (the highest amount tested in the study) for 3 weeks (duration of the study) did not cause any side effects

Table 5 Safe upper limits and recommended values of dietary protein intakes by healthy humans ${ }^{a}$

\begin{tabular}{|c|c|c|c|c|}
\hline \multirow[b]{2}{*}{ Group } & \multicolumn{2}{|c|}{$\begin{array}{l}\text { Safe upper } \\
\text { limits of } \\
\text { dietary protein } \\
\text { intake }\end{array}$} & \multicolumn{2}{|c|}{$\begin{array}{l}\text { Recommended } \\
\text { values of dietary } \\
\text { protein intake }\end{array}$} \\
\hline & Value & Ref. & Value & Ref. \\
\hline Infants ( 0.3 to 1 year of age) & 4.7 & 91 & 1.5 & 26 \\
\hline Children (1 to 3 years of age) & 5.1 & 92 & 1.1 & 26 \\
\hline Adults (>18 years of age) & 3.5 & $95-97$ & $1.0-1.6$ & $35,36,49$ \\
\hline Minimal physical activity & & & 1.0 & 35,36 \\
\hline Moderate physical activity & & & 1.3 & 49 \\
\hline Intense physical activity & & & 1.6 & 49 \\
\hline
\end{tabular}

${ }^{a}$ Values are expressed as g per kg body weight per day. 
in elite cyclists. ${ }^{94}$ Macdermid et al. ${ }^{95}$ reported that cyclists could well tolerate $3.3 \mathrm{~g}$ dietary protein per $\mathrm{kg}$ BW per day (the highest amount tested in the study) for 7 days (duration of the study). Furthermore, based on the capacity of urea synthesis, Bilsborough and Mann ${ }^{96}$ estimated that healthy adults can tolerate a dietary intake of $3.5 \mathrm{~g}$ protein per $\mathrm{kg}$ BW per day without side effects. This is equivalent to $280 \mathrm{~g}$ protein per day for an $80 \mathrm{~kg}$ subject. Interestingly, the Greenland Eskimos, who have lived on an almost exclusive meat diet for generations, consume daily $280 \mathrm{~g}$ protein, $135 \mathrm{~g}$ fat, and $54 \mathrm{~g}$ carbohydrate per person without renal or hepatic abnormality. ${ }^{97}$ However, a higher intake of protein may present a problem for some adults. In a recent study, forty healthy resistance-trained individuals were assigned to ingest $4.4 \mathrm{~g}$ protein per $\mathrm{kg}$ BW per day. ${ }^{98}$ The protein was derived from regular diet plus a mixture of whey and casein powder. Among the ten subjects who dropped out, three stated an inability to consume the required amount of protein and one subject complained about gastrointestinal distress. However, thirty subjects (including men and women with an average age of 24 years) could consume $4.4 \mathrm{~g}$ protein per $\mathrm{kg} \mathrm{BW}$ per day for 8 weeks without side effects. Based on these studies, it appears that welladapted healthy adults can tolerate a dietary intake of $3.5 \mathrm{~g}$ protein per $\mathrm{kg}$ BW per day for a prolonged period of time.

The average protein intake (e.g., $1.07 \mathrm{~g}$ per $\mathrm{kg} \mathrm{BW}$ per day for young adults) being $15 \%$ of dietary energy in the United States is well within the acceptable macronutrient distribution range ${ }^{26}$ but well below the recommended intake for most athletes. ${ }^{49}$ Even the 95th percentile of protein intake for United States adults is still far below the highest acceptable macronutrient distribution range for protein (i.e., $35 \%$ of dietary calories). Dietary intake of protein (up to $1.7 \mathrm{~g}$ protein per $\mathrm{kg}$ BW per day) recommended for athletes is well within the acceptable macronutrient distribution range. ${ }^{49}$ Based on an extensive review of the literature, Bilsborough and $\mathrm{Mann}^{96}$ suggested the maximum intake of 2 to $2.5 \mathrm{~g}$ protein per $\mathrm{kg}$ BW per day for healthy people, totaling 160 to $200 \mathrm{~g}$ protein per day for an $80 \mathrm{~kg}$ subject consuming $2900 \mathrm{kcal}$ daily. This is equivalent to $25 \%$ of dietary energy from protein.

\section{Concerns over adverse effects of high protein intake on human health}

\subsection{General considerations}

Healthy individuals have a high capacity to oxidize dietary AA and protein to form water-soluble metabolites, including ammonia, NO, homocysteine, and sulfate. ${ }^{1}$ In addition, bacteria in the intestines can produce beneficial (e.g., short-chain fatty acids) and potentially deleterious (e.g., $p$-cresol, skatole, and sulfide) metabolites from AA. ${ }^{99}$ In those subjects with adequate availability of arginine, ammonia is converted into urea primarily in the liver and, to a much lesser extent, in enterocytes of the small intestine. In addition, the kidneys remove $\mathrm{H}^{+}$by combining it with glutamine-derived $\mathrm{NH}_{3}$ to generate $\mathrm{NH}_{4}^{+}$. Urea and $\mathrm{NH}_{4}{ }^{+}$are then excreted in urine. When vita- mins $\mathrm{B}_{6}, \mathrm{~B}_{12}$ and folate are adequate, homocysteine (an oxidant) is rapidly recycled into methionine in the liver. ${ }^{1}$ As a vasodilator, $\mathrm{NO}$ increases blood flow and glomerular filtration rate. Thus, high protein intake (e.g., $>2 \mathrm{~g}$ per $\mathrm{kg}$ BW per day for adults) increases $\mathrm{N}$ loads to the gastrointestinal tract, liver, and kidneys.

Long-term consumption of any nutrients (including water, protein, and vitamin A) in high amounts may have adverse effects on human health. ${ }^{99}$ Protein intake greater than its safe upper limits in different age groups can exceed the ability of the liver, intestine, and kidneys to detoxify ammonia and should be avoided. Adverse effects of high protein intake include intestinal discomfort, hyperaminoacidemia, hyperammonemia, hyperinsulinemia, dehydration, irritation, nausea, diarrhea, liver and kidney injuries, fatigue, headache, seizures, high risk of cardiovascular disease, or even death. ${ }^{100}$ Problems of high protein intake can be exacerbated by low intake of carbohydrates because of additional burdens on the liver and kidney to produce large amounts of glucose from AA besides their roles in disposing of excessive ammonia and urea. Glucose is essential for meeting the energy requirements of the brain, red blood cells, renal medullar tissues, and retinal cells, and for the production of NADPH to support numerous biochemical (including anti-oxidative) reactions. Even during long-term starvation, the human brain still utilizes a large amount of glucose (i.e., $40 \%$ of the normal uptake of $125 \mathrm{~g}$ per day for a $70 \mathrm{~kg}$ person), and this glucose is derived primarily from AA.

\subsection{Digestive, renal or cardiovascular functions}

Excessive intake of protein or arginine is known to cause gastrointestinal discomfort due to a high rate of NO synthesis by mucosal cells. ${ }^{101}$ Likewise, elevated levels of homocysteine (a metabolite of methionine) in the plasma decrease NO bioavailability in endothelial cells by inhibiting NO synthesis and oxidizing NO, thereby causing vascular dysfunction. ${ }^{102}$ As the kidneys play important roles in the reabsorption of AA, as well as the urinary excretion of ammonia, urea and sulfate, ${ }^{1}$ dietary protein intake may affect renal function. ${ }^{103,104}$ For example, Rosenvinge et al. ${ }^{103}$ reported that in comparison with normal protein intake, dietary protein intake of $1.6 \mathrm{~g}$ per $\mathrm{kg}$ BW per day for 6 months increased the glomerular filtration rate by $5 \%$ and the kidney mass by $2.5 \%$ in healthy adults, which was an adaptive response to a high $\mathrm{N}$ load. In adults, the glomerular filtration rate reaches a maximum value at a dietary protein intake of $2 \mathrm{~g}$ per kg BW per day. ${ }^{104}$ When protein intake is $\leq 2 \mathrm{~g}$ per $\mathrm{kg}$ BW per day, there is little evidence of intestinal, hepatic, renal or cardiovascular dysfunction in healthy people. ${ }^{105}$ Furthermore, a diet providing protein intake as $25 \%$ of total energy (8.6-9.3 MJ per day) for 6 months does not affect renal function in overweight and obese subjects with no pre-existing kidney disease. ${ }^{106}$

Consumption of a weight-loss diet containing 90 to $120 \mathrm{~g}$ of protein per day did not affect renal function in overweight subjects or in obese adults with type-II diabetes, compared with those consuming 55 to $70 \mathrm{~g}$ protein per day. ${ }^{107}$ However, patients with renal dysfunction or gout are advised to consume an adequate amount of high-quality protein but not 
an excessive amount of protein. ${ }^{100}$ In addition, subjects who have consumed a low-protein diet for a prolonged period of time should not suddenly ingest large amounts of protein due to the reduced expression of hepatic urea-cycle enzymes for ammonia detoxification.

\subsection{Bone mass and health}

Efficient absorption of dietary minerals and mineralization depend on protein. ${ }^{108}$ In addition, protein is a major component of bones. Thus, adequate intake of protein, particularly from calcium- and phosphorus-rich milk products, is essential to support bone growth in infants and children and to sustain the mass and health of the skeleton in adults. There is a concern that high protein intake may stimulate urinary excretion of calcium, which may contribute to bone loss and subsequent development of osteopenia and osteoporosis. ${ }^{108}$ However, in free-living individuals, high protein intake is likely associated with high calcium intake, and, therefore, may compensate for a moderate increase, if any, in urinary excretion of calcium. Based on an extensive and systematic review of the literature, Sahni et al. ${ }^{109}$ concluded that dietary protein provided a significant benefit on bone health in humans. Likewise, there is evidence that adequate protein intake increases peak bone mass in both young and older adults. ${ }^{110,111}$ Thus, protein nutrition plays a key role in skeletal health to reduce risk for osteopenia and osteoporosis.

\subsection{Cancer and diabetes}

Recent epidemiological studies suggested that consumption of large quantities of protein (particularly animal protein) could be linked to an increase in risks of cancer and diabetes. ${ }^{112,113}$ Although some epidemiological research revealed a correlation between consumption of animal-based protein (e.g., red meats) and certain diseases (e.g., colon cancer and hypertension), it should be borne in mind that: (1) there is a clear difference between correlation and causation; and (2) the results of epidemiological studies do not establish a role for adequate consumption of animal-source protein (e.g., lean meat) in causing chronic diseases in humans. There are no rigorous long-term clinical trials involving meat-less diets for adults or children. Likewise, there is little evidence in human beings for the carcinogenicity of an adequate intake of animal protein. ${ }^{114}$ Lean meat is a major source of highquality protein for human consumption. ${ }^{30}$ Recent studies from large cohorts such as the Nurse's Health Study, the Health Professional Follow-up Study, and the Multiethnic Cohort showed non-significant associations and even inverse associations between consumption of unprocessed red meat and colorectal cancer. ${ }^{115,116}$ of note, findings from the intervention studies on diet and cancer, such as the Women's Health Initiative and the Polyp Prevention Trial, indicated that a decrease in dietary intake of animal protein (e.g., red meat and processed meat) did not reduce the risk of colorectal cancer and/or had no effect on adenoma recurrence in the large bowel. ${ }^{117-119}$

\section{Conclusion}

In summary, adequate consumption of high-quality protein is essential for optimal growth, development, and health in humans. An appropriate mixture of animal- and plant-based foods is a practical way to ensure balanced provision of dietary AA for the young and the adult. There is not a fixed amount of protein intake that suits all the people in all age groups. Rather, individuals should adjust their intake of protein and other nutrients according to metabolic rates, physiological needs, and health status. A sufficient supply of both EAA and synthesizable AA (so-called nutritionally nonessential AA) plays a key role in sustaining skeletal-muscle protein synthesis, mass, and function (including physical strength), while improving insulin sensitivity, ameliorating ageing-associated sarcopenia, and reducing whitefat accretion. In practice, adequate consumption of lean meat (a source of not only high-quality dietary protein but also vitamins and minerals) can help individuals realize the health benefits of moderate or intense exercise. To date, there are myths about AA and protein nutrition in humans due to inadequate understanding of the science. Sufficient intake of high-quality protein from animal products (e.g., lean meat and milk) is essential for optimal growth, development, and health of children, as well as for optimal maintenance, function and health of tissues (including skeletal muscle, brain, heart, kidneys, liver and gut) in adults. However, consumption of protein above safe upper limits should be avoided to prevent any adverse health problems.

\section{Abbreviations}

$\begin{array}{ll}\text { AA } & \text { Amino acid(s) } \\ \text { BW } & \text { Body weight } \\ \text { EAA } & \text { Nutritionally essential AA } \\ \text { mTOR } & \text { Mechanistic (mammalian) target of rapamycin } \\ \text { NEAA } & \text { Nutritionally nonessential AA } \\ \text { RDA } & \text { Recommended dietary allowance } \\ \text { RMR } & \text { Resting metabolic rate }\end{array}$

\section{Conflict of interest}

The author has no conflict of interest.

\section{Acknowledgements}

This work was supported, in part, by funds from National Council of Beef Association and Texas A\&M AgriLife Research (H-8200). The author thanks Dr H. Russell Cross and Shalene McNeill for helpful discussion.

\section{References}

1 G. Wu, Amino Acids: Biochemistry and Nutrition, CRC Press, Boca Raton, Florida, 2013. 
2 P. J. Reeds, D. G. Burrin, B. Stoll and J. B. van Goudoever, Nestle Nutr. Workshop Ser., Clin. Perform. Programme, 2000, 3, 25-40.

3 D. Tomé, Food Nutr. Bull., 2013, 34, 272-274.

4 A. San Gabriel and H. Uneyama, Amino Acids, 2013, 45, 451-461.

5 G. Wu, Amino acids: metabolism, functions, and nutrition, Amino Acids, 2009, 37, 1-17.

6 P. Li, Y. L. Yin, D. F. Li, S. W. Kim and G. Wu, Br. J. Nutr., 2007, 98, 237-252.

7 FAO, Dietary Protein Evaluation in Human Nutrition: Report of an FAO Expert Consultation, FAO, Rome (Italy), 2013.

8 M. Dasgupta, J. R. Sharkey and G. Wu, J. Nutr. Elderly, 2005, 24, 85-99.

9 L. J. Hoffer and B. R. Bistrian, Am. J. Clin. Nutr., 2012, 96, 591-600.

10 W. C. Rose, Am. J. Public Health, 1968, 58, 2020-2027.

11 R. Elango, R. O. Ball and P. B. Pencharz, Br. J. Nutr., 2012, 108(Suppl 2), S22-S30.

12 A. V. Kurpad and T. Thomas, Curr. Opin. Clin. Nutr. Metab. Care, 2011, 14, 434-439.

13 M. F. Fuller and P. J. Garlick, Annu. Rev. Nutr., 1994, 14, 217-241.

14 D. J. Millward, J. Nutr., 1997, 127, 1842-1846.

15 D. J. Millward, Am. J. Clin. Nutr., 2014, 100, 1210-1212.

16 J. von Liebig, Organic Chemistry in its Application to Agriculture and Physiology (Die Chemie in ihrer Anwendung auf Agricultur und Physiologie), Friedrich Vieweg, Berlin, Germany, 1840.

17 C. Voit, in Handbuch der Physiologie, ed. L. Hermann, Vogel, Leipzig, Germany, 1881, vol. 6, pp. 1-575.

18 W. O. Atwater, Principles of Nutrition and Nutritive Value of Food, USDA Farmers' Bull, no. 142, 1902.

19 R. H. Chittenden, Physiological Economy in Nutrition, Stokes, New York, NY, 1904.

20 V. R. Young and S. Borgonha, J. Nutr., 2000, 130, 1841S1849 S.

21 C. N. Meredith, Z. M. Wen, D. M. Bier, D. E. Matthews and V. R. Young, Am. J. Clin. Nutr., 1986, 43, 787-794.

22 FAO/WHO/UNU, Technical Report Series 935: Protein and Amino Acid Requirements in Human Nutrition, WHO Press, Geneva, Switzerland, 2007, pp. 1-265.

23 G. Wu, Z. L. Wu, Z. L. Dai, Y. Yang, W. W. Wang, C. Liu, B. Wang, J. J. Wang and Y. L. Yin, Amino Acids, 2013, 44, 1107-1113.

24 J. D. Kopple and M. E. Swendseid, J. Clin. Invest., 1975, 55, 881-891.

25 J. D. Kopple and M. E. Swendseid, J. Nutr., 1981, 111, 931942.

26 Institute of Medicine (IOM), Dietary Reference Intakes for Energy, Carbohydrates, Fiber, Fat, Fatty Acids, Cholesterol, Proteins, and Amino Acids, The National Academies Press, Washington, D.C., 2005.

27 L. E. Holt Jr. and A. A. Albanese, Trans. Assoc. Am. Physicians, 1944, 58, 143-156.
28 G. Wu, F. W. Bazer, M. C. Satterfield, X. L. Li, X. Q. Wang, G. A. Johnson, R. C. Burghardt, Z. L. Dai, J. J. Wang and Z. L. Wu, Amino Acids, 2013, 45, 241-256.

29 M. Elia, in Energy Metabolism: Tissue Determinants and Cellular Corollaries, ed. J. M. Kinney and H. N. Tucker, Raven Press, New York, 1992, pp. 61-79.

30 G. Wu, J. Fanzo, D. D. Miller, P. Pingali, M. Post, J. L. Steiner and A. E. Thalacker-Mercer, Ann. N. Y. Acad. Sci., 2014, 1321, 1-19.

31 J. J. Wang, Z. L. Wu, D. F. Li, N. Li, S. V. Dindot, M. C. Satterfield, F. W. Bazer and G. Wu, Antioxid. Redox Signaling, 2012, 17, 282-301.

32 R. R. Wolfe, Am. J. Clin. Nutr., 2006, 84, 475-482.

33 W. M. Rand, P. L. Pellett and V. R. Young, Am. J. Clin. Nutr., 2003, 77, 109-127.

34 G. Wu, C. J. Meininger, D. A. Knabe, F. W. Bazer and J. M. Rhoads, Curr. Opin. Clin. Nutr. Metab. Care, 2000, 3, 59-66.

35 B. E. Phillips, D. S. Hill and P. J. Atherton, Curr. Opin. Clin. Nutr. Metab. Care, 2012, 15, 58-63.

36 E. Volpi, W. W. Campbell, J. T. Dwyer, M. A. Johnson, G. L. Jensen, J. E. Morley and R. R. Wolfe, J. Gerontol. A Biol. Sci. Med. Sci., 2013, 68, 677-681.

37 J. Bohe, J. F. Low, R. R. Wolfe and M. J. Rennie, J. Physiol., 2001, 532, 575-579.

38 B. B. Rasmussen, K. D. Tipton, S. L. Miller, S. E. Wolf and R. R. Wolfe, J. Appl. Physiol., 2000, 88, 386-392.

39 K. Yao, Y. L. Yin, Z. M. Feng, Z. R. Tang, J. Fang and G. Wu, Front. Biosci., 2011, S3, 286-297.

40 W. W. Wang, Z. L. Dai, Z. L. Wu, G. Lin, S. C. Jia, S. D. Hu, S. Dahanayaka and G. Wu, Amino Acids, 2014, 46, 20372045.

41 Y. Q. Hou, Y. L. Yin and G. Wu, Exp. Biol. Med., 2015, 240, 997-1007.

42 G. Wu, J. Anim. Sci. Biotechnol., 2014, 5, 34.

43 W. W. Campbell, T. A. Trappe, R. R. Wolfe and W. J. Evans, J. Gerontol. A Biol. Sci. Med. Sci., 2001, 56, M373-M380.

44 W. W. Campbell, T. A. Trappe, A. C. Jozsi, L. J. Kruskall, R. R. Wolfe and W. J. Evans, J. Physiol., 2002, 542, 631642.

45 D. K. Houston, B. J. Nicklas, D. Jingzhong, T. B. Harris, F. A. Tylavsky, A. B. Newman, J. S. Lee, N. R. Sahyoun, M. Visser and S. B. Kritchevsky, Am. J. Clin. Nutr., 2008, 87, 150-155.

46 S. Ringholm, R. S. Bienso, K. Kiilerish, A. GuadalupeGrau, N. J. Aachmann-Andersen, B. Saltin, P. Plomgaard, C. Lundby, J. F. Wojtaszewski, J. A. Calbet and H. Pilegaard, Am. J. Physiol. Endocrinol. Metab., 2011, 301, E649-E658.

47 N. A. Burd, D. W. West, D. R. Moore, P. J. Atherton, A. W. Staples, T. Prior, J. E. Tang, M. J. Rennie, S. K. Baker and S. M. Phillips, J. Nutr., 2011, 141, 568-573.

48 D. K. Layman, T. G. Anthony, B. B. Rasmussen, S. H. Adams, C. J. Lynch, G. D. Brinkworth and T. A. Davis, Am. J. Clin. Nutr., 2015, 101, 1330S-1338S. 
49 ACSM, Med. Sci. Sports Exerc., 2009, 41, 709-731.

50 M. J. Rennie, R. H. Edwards, S. Krywawych, C. T. Davies, D. Halliday, J. C. Waterlow and D. J. Millward, Clin. Sci., 1981, 61, 627-639.

51 V. R. Young and B. Torún, Report No. EPR/81/28A, FAO/ WHO/UNU, 1981.

52 L. E. Norton and D. K. Layman, J. Nutr., 2006, 136, 533SS537.

53 P. W. Lemon, D. G. Dolny and K. E. Yarasheski, Can. J. Appl. Physiol., 1997, 22, 494-503.

54 G. Biolo, K. D. Tipton, S. Klein and R. R. Wolfe, Am. J. Physiol., 1997, 273, E122-E129.

55 S. M. Phillips, K. D. Tipton, A. Aarsland, S. E. Wolf and R. R. Wolfe, Am. J. Physiol., 1997, 273, E99-107.

56 B. B. Rasmussen and S. M. Phillips, Exerc. Sport Sci. Rev., 2003, 31, 127-131.

57 D. A. Columbus, M. L. Fiorotto and T. A. Davis, Amino Acids, 2015, 47, 259-270.

58 C. He, R. Sumpter Jr. and B. Levine, Autophagy, 2012, 8, 1548-1551.

59 A. H. Forslund, A. E. El-Khoury, R. M. Olsson, A. M. Sjodin, L. Hambraeus and V. R. Young, Am. J. Physiol., 1999, 276, E964-E976.

60 D. K. Layman, E. Evans, J. I. Baum, J. Seyler, D. J. Erickson and R. A. Boileau, J. Nutr., 2005, 135, 1903-1910.

61 S. van Vliet, N. A. Burd and L. J. C. van Loon, J. Nutr., 2015, 145, 1981-1991.

62 D. K. Levenhagen, J. D. Gresham, M. G. Carlson, D. J. Maron, M. J. Borel and P. J. Flakoll, Am. J. Physiol. Endocrinol. Metab., 2001, 280, E982-E993.

63 M. Leenders, L. B. Verdijk, L. van der Hoeven, J. van Kranenburg, F. Hartgens, W. K. Wodzig, W. H. Saris and L. J. van Loon, J. Nutr., 2011, 141, 1070-1076.

64 W. S. Jobgen, S. K. Fried, W. J. Fu, C. J. Meininger and G. Wu, J. Nutr. Biochem., 2006, 17, 571-588.

65 E. Agostinelli, Amino Acids, 2004, 46, 475-485.

66 A. Lombardi, M. Moreno, P. de Lange, S. Iossa, R. A. Busiello and F. Goglia, Front. Physiol., 2015, 6, 237.

67 J. T. Brosnan and M. E. Brosnan, Annu. Rev. Nutr., 2007, 27, 241-261.

68 A. R. Josse, S. A. Atkinson, M. A. Tarnopolsky and S. M. Phillips, J. Nutr., 2011, 141, 1626-1634.

69 J. R. McKnight, M. C. Satterfield, W. S. Jobgen, S. B. Smith, T. E. Spencer, C. J. Meininger, C. J. McNeal and G. Wu, Amino Acids, 2010, 39, 349-357.

70 H. J. Leidy, P. M. Clifton, A. Astrup, T. P. Wycherley, M. S. Westerterp-Plantenga, N. D. Luscombe-Marsh, S. C. Woods and R. D. Mattes, Am. J. Clin. Nutr., 2015, 101, 1320S-1329S.

71 C. Fromentin, D. Tomé, F. Nau, L. Flet, C. Luengo, D. Azzout-Marniche, P. Sanders, G. Fromentin and C. Gaudichon, Diabetes, 2013, 62, 1435-1442.

72 M. M. Mamerow, J. A. Mettler, K. L. English, S. L. Casperson, E. Arentson-Lantz, M. Sheffield-Moore, D. K. Layman and D. Paddon-Jones, J. Nutr., 2014, 144, 876-880.
73 X. L. Li, R. Rezaei, P. Li and G. Wu, Amino Acids, 2011, 40, 1159-1168.

74 G. Wu, F. W. Bazer and H. R. Cross, Land-based production of animal protein: impacts, efficiency, and sustainability, Ann. N. Y. Acad. Sci., 2014, 1328, 18-28.

75 J. W. Hartman, J. E. Tang, S. B. Wilkinson, M. A. Tarnopolsky, R. L. Lawrence, A. V. Fullerton and S. M. Phillips, Am. J. Clin. Nutr., 2007, 86, 373-381.

76 J. S. Volek, B. M. Volk, A. L. Gomez, L. J. Kunces, B. R. Kupchak, D. J. Freidenreich, J. C. Aristizabal, C. Saenz, C. Dunn-Lewis, K. D. Ballard, et al., J. Am. Coll. Nutr., 2013, 32, 122-135.

77 M. Aubertin-Leheudre and H. Adlercreutz, Br. J. Nutr., 2009, 102, 1803-1810.

78 B. Pennings, Y. Boirie, J. M. Senden, A. P. Gijsen, H. Kuipers and L. J. van Loon, Am. J. Clin. Nutr., 2011, 93, 997-1005.

79 L. Holm, J. L. Olesen, K. Matsumoto, T. Doi, M. Mizuno, T. J. Alsted, A. L. Mackey, P. Schwarz and M. Kjaer, J. Appl. Physiol., 2008, 105, 274-281.

80 L. B. Verdijk, R. A. M. Jonkers, B. G. Gleeson, M. Beelen, K. Meijer, H. H. Savelberg, W. K. Wodzig, P. Dendale and L. J. van Loon, Am. J. Clin. Nutr., 2009, 89, 608-616.

81 S. Akibode and M. Maredia, Global and regional trends in production, trade and consumption of food legume crops, Michigan State University, 2011.

82 B. Dorner, E. K. Friedrich and M. E. Posthauer, J. Am. Diet. Assoc., 2010, 110, 1549-1553.

83 S. Dodson, V. E. Baracos, A. Jatoi, W. J. Evans, D. Cella, J. T. Dalton and M. S. Steiner, Annu. Rev. Med., 2011, 62, 265-279.

84 United Nations, World population prospects. http://www. un.org, 2014.

85 F. Viteri, M. Béhar, G. Arroyave and N. S. Scrimshaw, in Mammalian Protein Metabolism, ed. H. N. Munro and J. B. Allison, Academic Press, New York, 1964, vol. 2.

86 L. Q. He, L. Wu, Z. Q. Xu, T. J. Li, K. Yao, Z. J. Cui, Y. L. Yin and G. Wu, Amino Acids, 2016, 48, 21-30.

87 A. E. Harper and N. N. Yoshimura, Nutrition, 1993, 9, 460469.

88 G. Wu, B. Imhoff-Kunsch and A. W. Girard, Paediatr. Perinat. Epidemiol., 2012, 26(Suppl. 1), 4-26.

89 M. Grillenberger, C. G. Neumann, S. P. Murphy, N. O. Bwibo, P. van't Veer, J. G. Hautvast and C. E. West, J. Nutr., 2003, 133, 3957S-3964S.

90 D. K. Dror and L. H. Allen, Food Nutr. Bull., 2011, 32, $227-$ 243.

91 K. F. Michaelsen, Acta Paediatr., 1997, 86, 1-36.

92 M. F. Rolland-Cachera, M. Deheeger and F. Bellisle, Acta Paediatr., 1999, 88, 365-367.

93 C. Hoppe, T. R. Udam, L. Lauritzen, C. Mølgaard, A. Juul and K. F. Michaelsen, Am. J. Clin. Nutr., 2004, 80, 447452.

94 O. C. Witard, S. R. Jackman, A. K. Kies, A. E. Jeukendrup and K. D. Tipton, Med. Sci. Sports Exerc., 2011, 43, 598-607. 
95 P. W. Macdermid and S. R. Stannard, Int. J. Sport Nutr. Exerc. Metab., 2006, 16, 65-77.

96 S. Bilsborough and N. Mann, Int. J. Sport Nutr. Exerc. Metab., 2006, 16, 129-152.

97 W. McClelland and E. DuBois, J. Biol. Chem., 1930, 87, 651-680.

98 J. Antonio, C. A. Peacock, A. Ellerbroek, B. Fromhoff and T. Silver, J. Int. Soc. Sports Nutr., 2014, 11, 19.

99 F. Blachier, F. Mariotti, J. F. Huneau and D. Tomé, Effects of amino acid-derived luminal metabolites on the colonic epithelium and physiopathological consequences, Amino Acids, 2007, 33, 547-562.

100 N. Santesso, E. A. Akl, M. Bianchi, A. Mente, R. Mustafa, D. Heels-Ansdell and H. J. Schünemann, Eur. J. Clin. Nutr., 2012, 66, 780-788.

101 G. K. Grimble, J. Nutr., 2007, 137(Suppl 2), 1693S-1701S.

102 G. Wu and C. J. Meininger, Regulation of nitric oxide synthesis by dietary factors, Annu. Rev. Nutr., 2002, 22, 61-86.

103 S. A. Rosenvinge, A. Toubro, J. Bülow, K. Krabbe, H. H. Parving and A. Astrup, Int. J. Obes., 1999, 23, 11701177.

104 E. Brändle, H. G. Siebert and R. E. Hautmann, Eur. J. Clin. Nutr., 1996, 50, 734-740.

105 A. N. Pedersen, J. Kondrup and E. Børsheim, Food Nutr. Res., 2013, 57, 21245.

106 A. R. Skov, S. Toubro, B. Ronn, L. Holm and A. Astrup, Int. J. Obes. Relat. Metab. Disord., 1999, 23, 528-536.

107 D. R. Jesudason, E. Pedersen and P. M. Clifton, Am. J. Clin. Nutr., 2013, 98, 494-501.

108 J. P. Bonjour, Int. J. Vitam. Nutr. Res., 2011, 81, 134-142.

109 S. Sahni, K. E. Broe, K. L. Tucker KL, R. R. McLean, D. P. Kiel, L. A. Cupples and M. T. Hannan, Public Health Nutr., 2013, 29, 1-7.
110 R. P. Heaney and D. K. Layman, Am. J. Clin. Nutr., 2008, 87, 1567S-1570S.

111 J. P. Bonjour, J. Am. Coll. Nutr., 2005, 24(6 Suppl), 526S$536 \mathrm{~S}$.

112 M. E. Levine, J. A. Suarez, S. Brandhorst, P. Balasubramanian, C. W. Cheng, F. Madia, L. Fontana, M. G. Mirisola, J. Guevara-Aguirre, J. Wan, G. Passarino, B. K. Kennedy, M. Wei, P. Cohen, E. M. Crimmins and V. D. Longo, Cell Metab., 2014, 19, 407-417.

113 M. van Nielen, E. J. Feskens, M. Mensink, I. Sluijs, E. Molina, P. Amiano, et al., Diabetes Care, 2014, 37, 18541862.

114 D. D. Alexander, D. L. Weed, P. E. Miller and M. A. Mohamed, J. Am. Coll. Nutr., 2015, 34, 521-543.

115 A. M. Bernstein, M. Song, X. Zhang, A. Pan, M. Wang, C. S. Fuchs, N. Le, A. T. Chan, W. C. Willett, S. Ogino, E. L. Giovannucci and K. Wu, PLoS One, 2015, 10(8), e0135959.

116 N. J. Ollberding, L. R. Wilkens, B. E. Henderson, L. N. Kolonel and L. Le Marchand, Int. J. Cancer, 2012, 131, E1125-E1133.

117 S. A. Beresford, K. C. Johnson, C. Ritenbaugh, N. L. Lasser, L. G. Snetselaar, H. R. Black, G. L. Anderson, A. R. Assaf, T. Bassford, D. Bowen, et al., J. Am. Med. Assoc., 2006, 295, 643-654.

118 A. Schatzkin, E. Lanza, D. Corle, P. Lance, F. Iber, B. Caan, M. Shike, J. Weissfeld, R. Burt, M. R. Cooper, J. W. Kikendall and J. Cahill, N. Engl. J. Med., 2000, 342, 1149-1155.

119 E. Lanza, A. Schatzkin, C. Daston, D. Corle, L. Freedman, R. Ballard-Barbash, B. Caan, P. Lance, J. Marshall, F. Iber, M. Shike, J. Weissfeld, M. Slattery, E. Paskett, D. Mateski and P. Albert, Am. J. Clin. Nutr., 2001, 74, 387-401. 